\title{
研究論文
}

\section{多様なバイオマス資源の組成・熱分解分析から抽出した特性とその相関 \\ A Property Extracted by Composition / Thermal Decomposition Analyses of Various Biomass Resources and Its Correlation}

\author{
水野 諭*・森田明 宏*・井田民男*・難 波邦彦**・渕端＼cjkstart学*・澤 井＼cjkstart徹*** \\ Satoru MIZUNO, Akihiro MORITA, Tamio IDA, Kunihiko NAMBA, Manabu FUCHIHATA and Toru SAWAI
}

(Received May 2, 2008)

\begin{abstract}
Effective utilization of biomass resource rapidly has been promoting since the government adopted the 'Biomass Nippon' strategy at a cabinet meeting in 2002. Especially, the energy conversion technology of applying biomass has been expected from a point of view of environment and resource conservation. However, the energy conversion technologies are developed only for woody and herby biomass, and not for all of biomass. A stable supply of large quantity of biomass will be pressed in the future because the conversion technology must expand to use a variety of biomass. This study is to consider ways by various quantitative correlation analyses between the atomic composition and thermal decomposition of various biomass samples. The results found that thermal decomposition analyses of various biomass resources have correlations between atomic composition properties and exothermic properties.
\end{abstract}

Key Words: Widely Biomass Resource, Thermal Decomposition Analysis, Exothermic Property, Atomic Composition Property

\section{1. 緒 言}

国内バイオマスの利活用は、平成 12 年に閣議決定され た「バイオマス・ニッポン総合戦略」およびその後のロー ドマップにより、加速的にその利活用の開発が進められて いる。 ${ }^{1), 2)}$ しかし、その転換技術によって主たる対象は木質 系バイオマスあるいは草本系バイオマス等に限られ、市場 展開も限られているきらいがある。今後、バイオマスの転 換技術が発展し、その利活用が促進されるとバイオマスの バリエーションを広くし、多くのバイオマス量を安定供給 することが求められる。

本研究では、新機能を有した固形燃料の開発を促進する ために、バイオマスの骨格構造であるセルロース、へミセ ルロース、リグニンの含有比率の差異と CHN（炭素、水素、 窒素）の原子比率の差異に着目し、広範囲なバイオマスの 熱分解特性を定量的に解析し、そのグルーピングを検討す ることを目的とした。試料として、木質系バイオマス、農 産系バイオマス、食品残椬系バイオマス、果樹系バイオマ スから代表的なバイオマスを選出し、その熱分析特性の変 化を抽出し、それらの関連性について検討を行った。

\section{2. 分析手法}

バイオマスの熱分解特性は、セルロース、ヘミセルロー ス、リグニンの主要 3 成分の含有比率とその形態構造に寄っ ていることは周知のことである。( ${ }^{4)}$ 試料として、木質系 バイオマスでは、針葉樹としてスギ幹部とスギ樹皮を、広 葉樹としてコナラ幹部と兴幹を選定した。草本系バイオマ スでは、河川敷に生育する蔁および里山での処理で問題と なっている竹を選定した。農産系バイオマスでは、野菜の 生産調整で毎年、掘埋廃衰されるブロッコリーを、食品加 工残椬では、社会的なブームの影で大量に廃亲され続けて いる芋焼酎滓とオカラを選定した。厨芥加工残椬系バイオ マスでは、国内市場に多いコーヒー滓とペットボトル販売 で大量廃棄されるお茶滓を選定した。果樹系バイオマスで は、季節的に大量に廃棄される桃剪定材と、ジュース販売 により地方で廃棄されるリンゴ絞り滓およびバナナの皮を 選定した。

\section{1 示差熱熱重量同時測定装置 (TG/DTA)}

示差熱熱重量同時測定装置の構成を Fig.1に、熱分析条 件をTable 1 に示す。電気炉内は $\pm 5 \mathrm{~K}$ の範囲で温度設定

*近畿大学 理工学部（干 577-8502 大阪府東大阪市小若江 3-4-1）

Kinki University (3-4-1 Kowakae, Higashiosaka, Osaka 577-8502, Japan)

**大阪府立工業高等専門学校（５ 572-8572 大阪府寝屋川市幸町 26-12）

Osaka Prefectural College of Technology (26-12 Saiwaicho, Neyagawa, Osaka 572-8572, Japan)

$* * *$ 近畿大学生物理工学部（～７49-649 和歌山県紀の川市西三谷 930）

Kinki University（930 Nishimitani, Kinokawa, Wakayama 649-6493, Japan） 
Section of Supporting Point

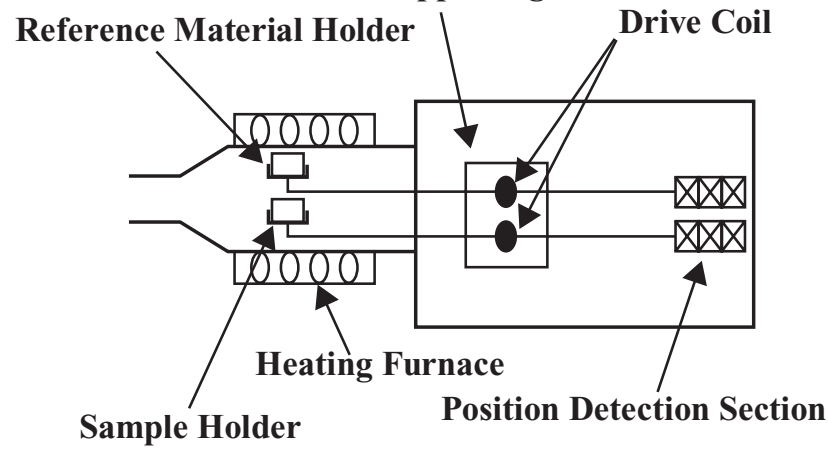

Fig.1 Schematic of TG/DTA Device

Table 1 Conditions of Thermal Analysis

\begin{tabular}{c|c}
\hline Sample weight $(\mathrm{mg})$ & 10 \\
\hline Gas flow rate $\left(\mathrm{cm}^{3} / \mathrm{min}\right)$ & 200 \\
\hline Gas atmosphere & $\mathrm{N}_{2}$, Air \\
\hline Max temperature $(\mathrm{K})$ & 1273 \\
\hline Heating rate $(\mathrm{K} / \mathrm{min})$ & 10 \\
\hline
\end{tabular}

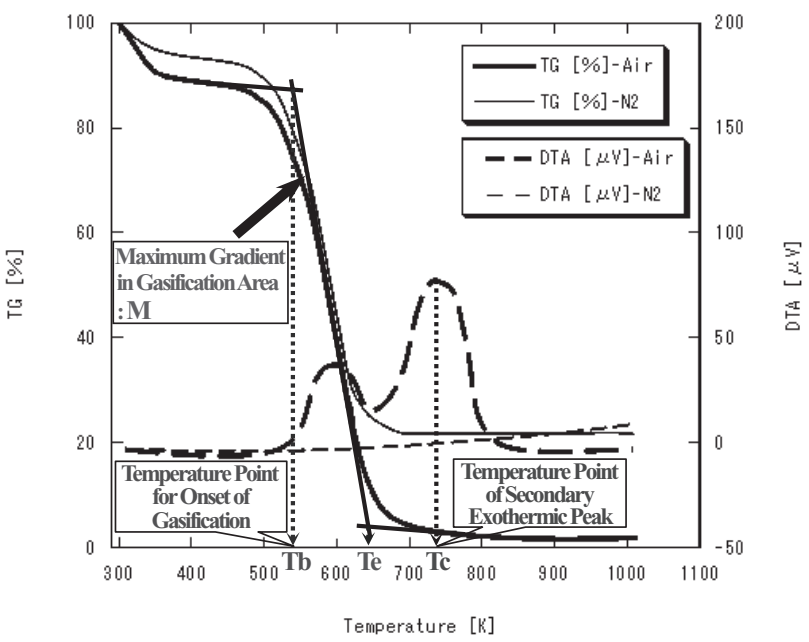

Fig.2 Example of Thermal Decomposition Curves and Conditional Points and Term of Gradient for Effect of Gasification, Heavy Lines Correspond to Active(Air) Environment and Fine Lines Correspond to Passive $\left(\mathrm{N}_{2}\right)$ Environment

が可能であり、試料の粒子中心部の温度測定には $\phi 0.3 \mathrm{~mm}$ の Pt/Pt-13\%Rh 熱電対を用いた。

\section{2 特性曲線解析手法}

本研究では、各種バイオマスの熱分解特性を定量的に検 討するために、示差熱熱重量同時測定により得られた重量 (TG) 収率曲線と吸発熱特性 (DTA) 曲線からその変化を抽出 し解析を行った。

Fig.2にTG/DTA 曲線の例とその抽出ポイントを示す。

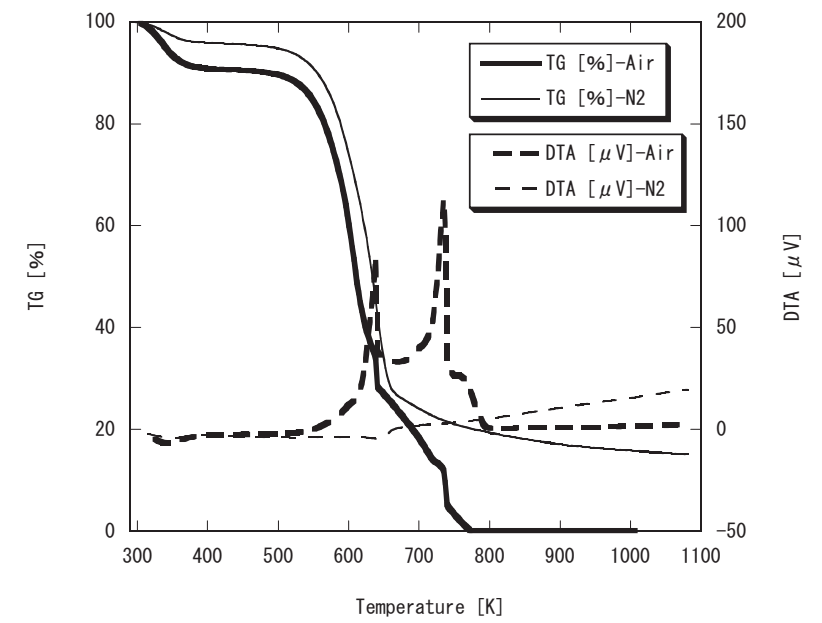

Fig.3 Thermal Decomposition Curve for Trunk of Cedar

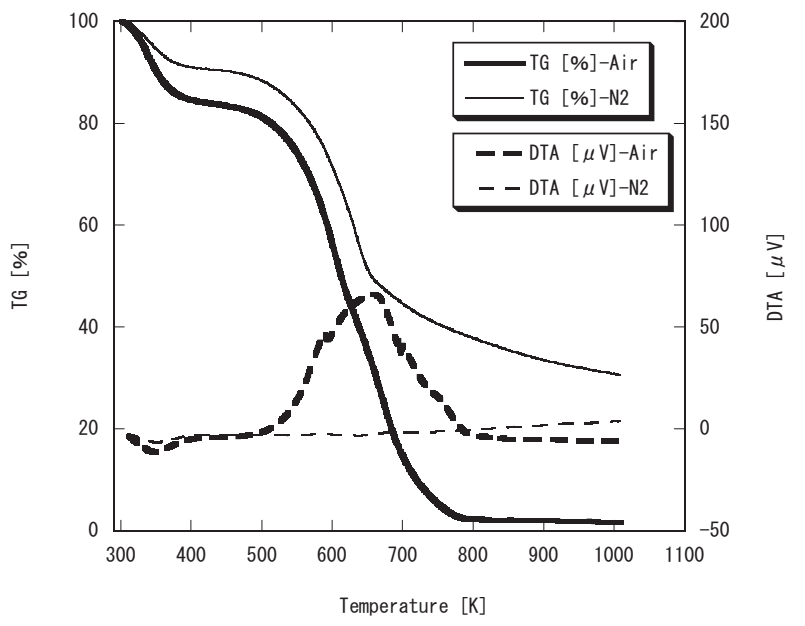

Fig.4 Thermal Decomposition Curve for Bark of Cedar

ここで、太いラインが活性（空気）雲囲気での特性曲線を 示し、細いラインが不活性（窒素）雲囲気での特性曲線を 示している。左縦軸が重量収率を、右縦軸が吸発熱特性を 示している。

バイオマスの熱分解特性を定量的に評価するためのポ イントとして、TG曲線からガス化開始温度を $\mathrm{Tb}$ 点 $(\mathrm{K}) 、$ DTA 曲線から炭素成分の表面燃焼による2つめの発熱ピー ク温度を $\mathrm{Tc}$ 点 $(\mathrm{K})$ とした。亘後述のバイオマスサンプルか ら鑑み、 $\mathrm{Tb}$ 点については、セルロース、ヘミセルロースの 含有比率の異なるバイオマスにおいてその差異が抽出でき ること、Tc 点については、主にリグニンに起因する固定炭 素の形態構造に差異が認められることから設定した。さら に、TG曲線よりガス化終了温度 $\mathrm{Te}$ 点 $(\mathrm{K})$ を設け、温度幅 に対するガス化率に影響する観点からガス化開始温度 $\mathrm{Tb}$ 点 $(\mathrm{K})$ とガス化終了温度 $\mathrm{Te}$ 点 $(\mathrm{K})$ を結んだときの直線の傾 き度 M $(1 / \mathrm{K})$ を抽出項目として設定した。 


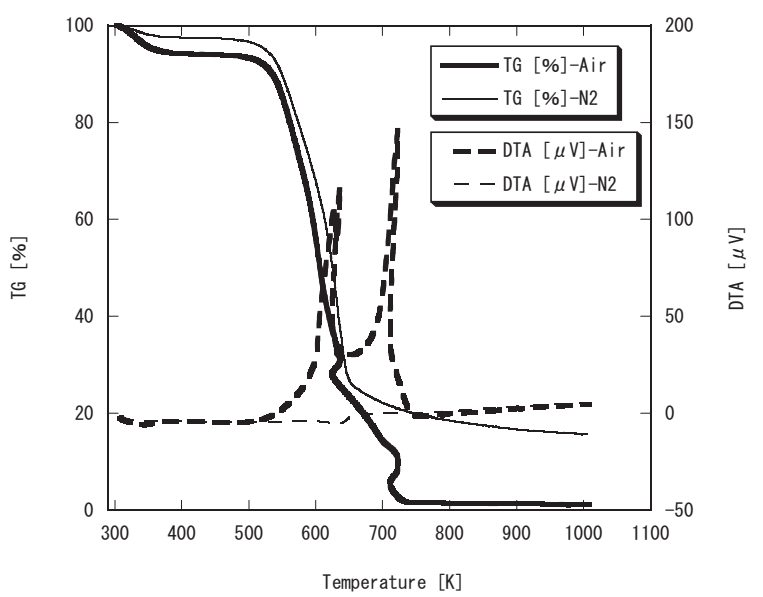

Fig.5 Thermal Decomposition Curve for Konara Oak

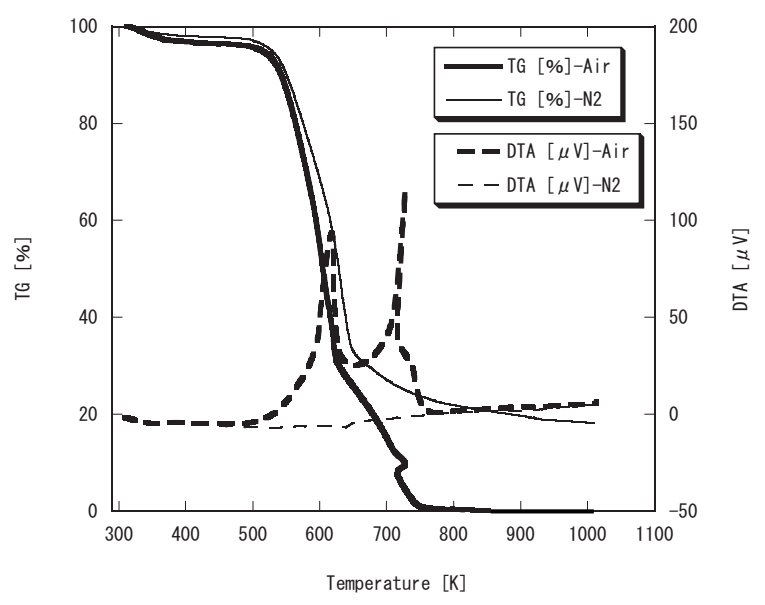

Fig.6 Thermal Decomposition Curve for Sakura

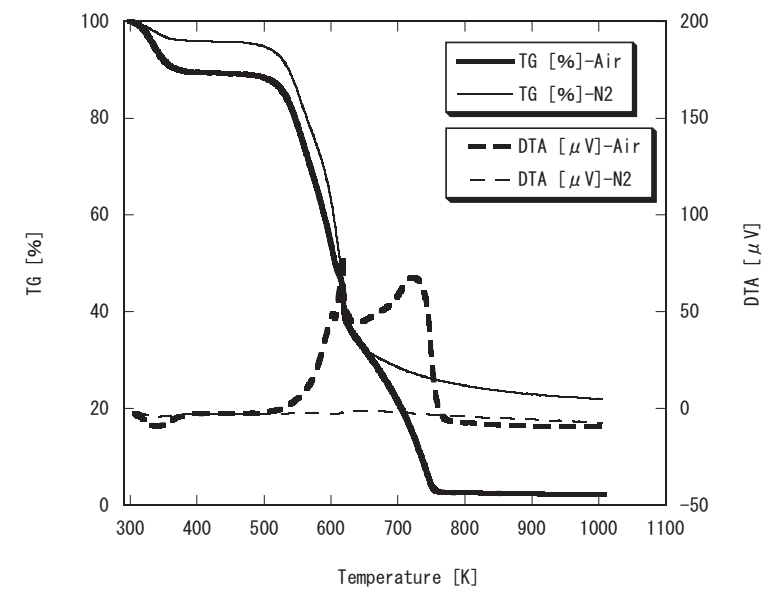

Fig.7 Thermal Decomposition Curve for Reed

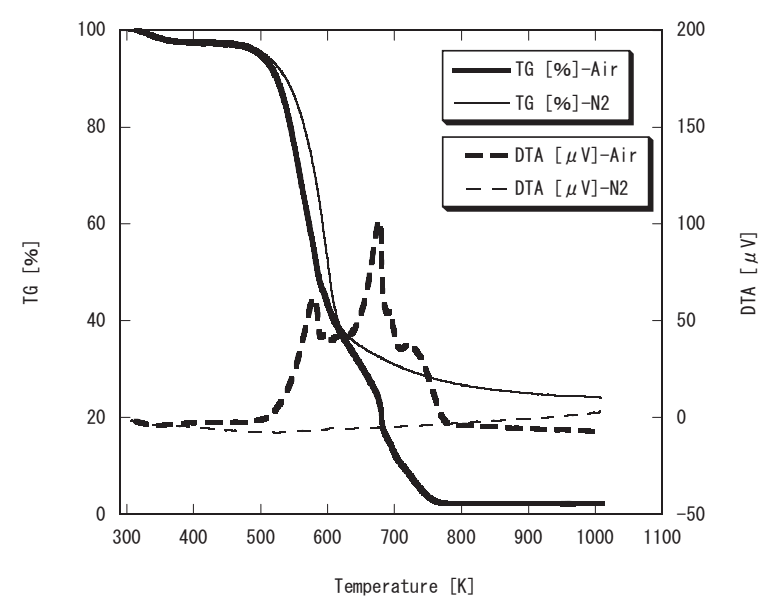

Fig.8 Thermal Decomposition Curve for Bamboo
以上、2つの抽出点と 1 つの抽出項目により、各バイオ マスの単位重量発熱量（MJ/kg）［JIS M 8814 準拠にて分析］ と炭素分率 (wt\%) [CHN 分析值 (JIS M 8813 準拠にて分析) より抽出）との連関を調べ、そのマッピングによりグルー ピングを行った。

\section{3. 示差熱分解特性}

\section{1 木質系バイオマス}

\subsection{1 針葉樹}

スギ幹部、スギ樹皮の熱分解特性を Fig.3、Fig.4に示す。

Fig.3、Fig.4 より、ガス化開始温度 Tb 点が幹部は 570K、

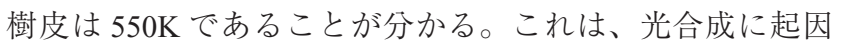
するバイオマスが有する主要 3 成分のうち、セルロースお よびヘミセルロースの含有比率が樹皮よりも幹部の方が多 いためであると推察される。出,7)

2 つめの発熱ピーク温度 Tc 点では、幹部が $730 \mathrm{~K} 、$ 樹皮 が $660 \mathrm{~K}$ であった。その時の DTA 曲線の形状を見ると、幹 部がスパイク状の曲線を描いているのに対し、樹皮は緩慢
な山状の曲線を描いている。これは、幹部と樹皮に含まれ る固定炭素の形態に違いがあり、幹部の方が温度に対して 鋭敏でガス化速度が速いことを示唆している。

ガス化領域における最大傾斜度 $\mathrm{M}$ は、幹部が $1.0 \times 10^{-2}(1 /$ $\mathrm{K}) 、$ 樹皮が $0.48 \times 10^{-2}(1 / \mathrm{K})$ であった。このことは、温度 幅に対するガス化率が樹皮に比べ、幹部の方が多くなって いることを示している。

\section{1 .2 広葉樹}

Fig.5、Fig.6 にコナラと桜の熱分解特性を示す。

コナラと桜のガス化開始温度 $\mathrm{Tb}$ 点はともに $560 \mathrm{~K}$ であ り、DTA 曲線の第 2 の発熱ピーク温度 Tc 点は、コナラが $720 \mathrm{~K} 、$ 桜が730K であった。さらに、ガス化領域における 傾斜度 M は、コナラが $1.0 \times 10^{-2}(1 / \mathrm{K})$ 、桜が $0.77 \times 10^{-2}(1 /$ K)であった。

これらの結果と TG 曲線と DTA 曲線の形状が酷似してい ることから、コナラと桜の主要成分の含有比率はほほ同じ であるものと推察される。 
多様なバイオマス資源の組成·熱分解分析から抽出した特性とその相関（水野·森田・井田・難波・㴊端・澤井）

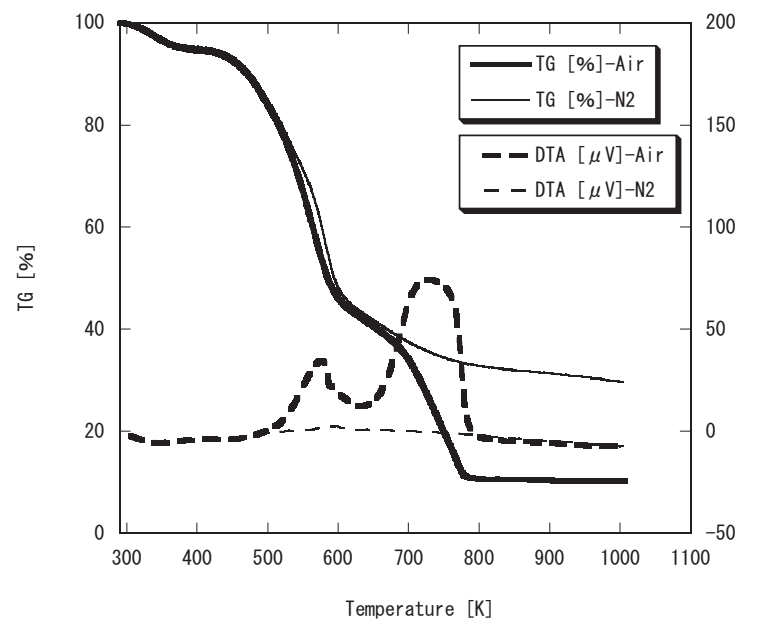

Fig.9 Thermal Decomposition Curve for Broccoli

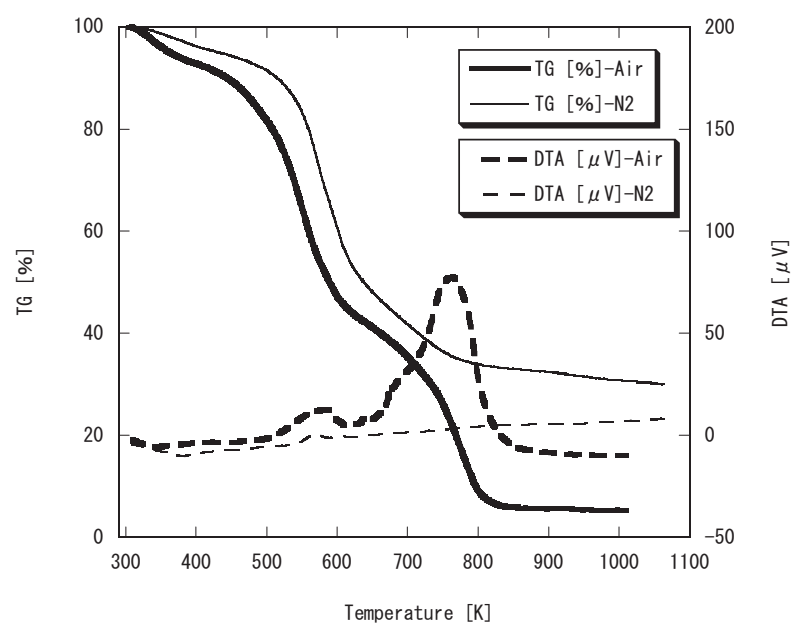

Fig.10 Thermal Decomposition Curve for Distilled Spirit Grounds

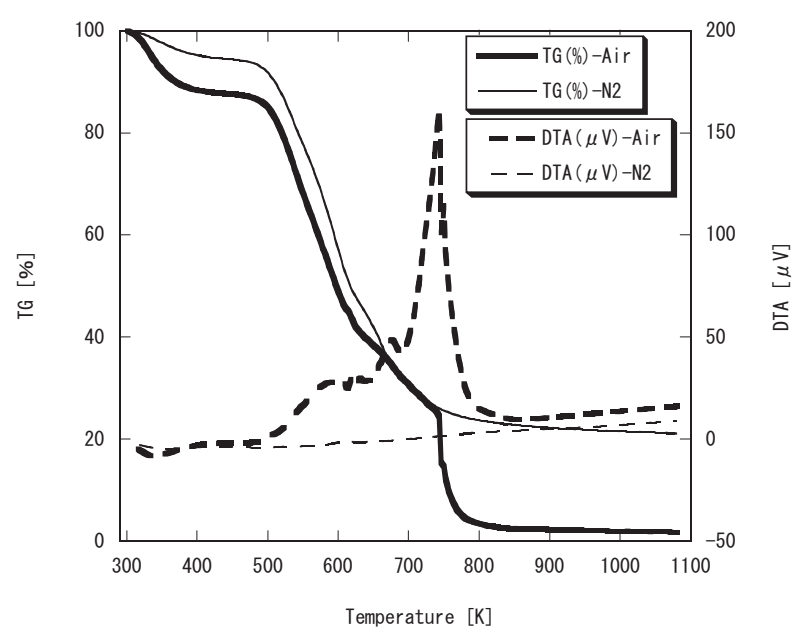

Fig.11 Thermal Decomposition Curve for Bean Curd Refuse

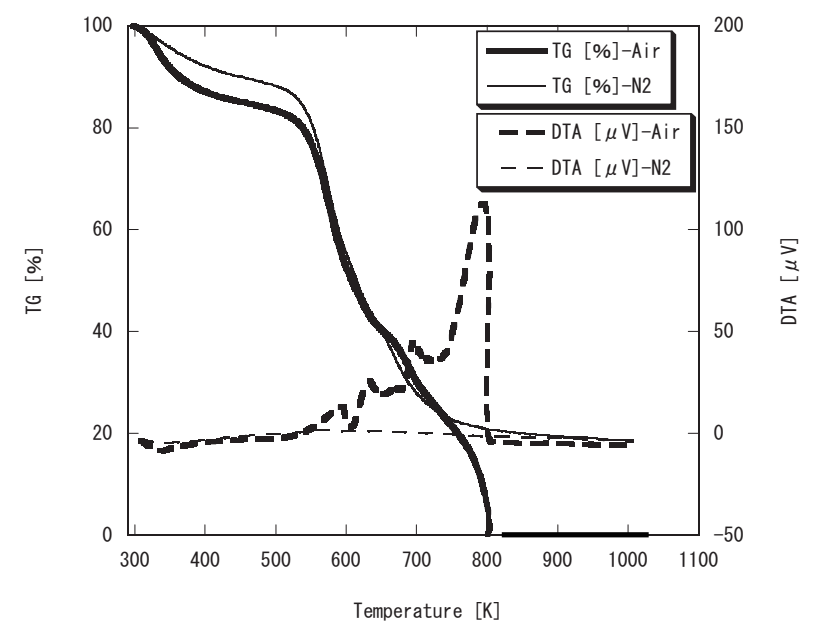

Fig.12 Thermal Decomposition Curve for Coffee Grounds

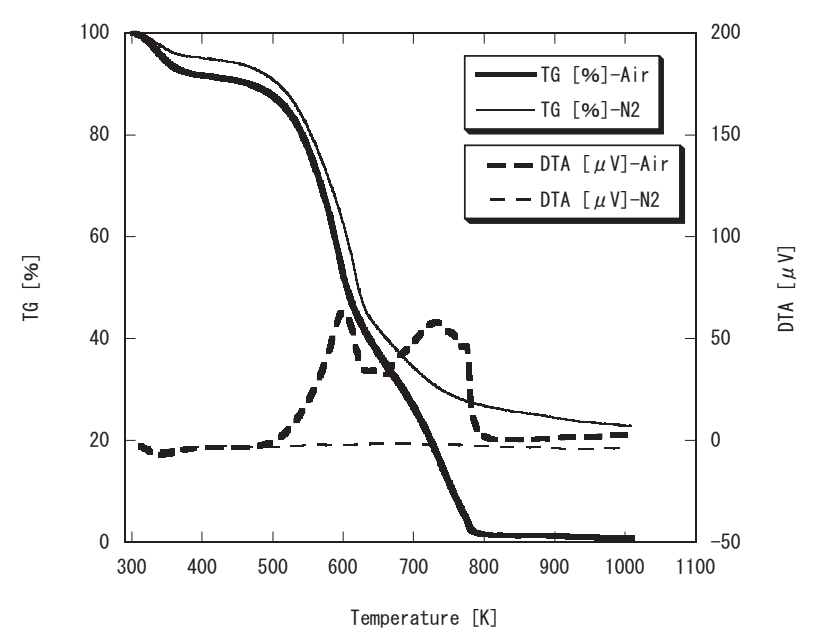

Fig.13 Thermal Decomposition Curve for Tea Grounds

\section{2 草本系バイオマス}

Fig.7、Fig.8に蔁と竹の熱分解特性を示す。

ガス化開始温度 $\mathrm{Tb}$ 点は、蔁が $550 \mathrm{~K} 、$ 竹が $530 \mathrm{~K}$ であり、 DTA 曲線の Tc 点は、莘が $730 \mathrm{~K} 、$ 竹が $680 \mathrm{~K}$ であることが 分かる。

また、ガス化領域における最大傾斜度 $\mathrm{M}$ に関しては、莘 が $0.59 \times 10^{-2}(1 / \mathrm{K}) 、$ 竹が $0.77 \times 10^{-2}(1 / \mathrm{K})$ であることが分かっ た。

これらの結果と DTA 曲線の Tc 点の差異および葦の Tc 点における緩慢な発熱特性に着目すると、莘の固定炭素の 形態は竹と異なり、よりガス化しにくい形態をとっている ことが理解できる。

\section{3 農産系バイオマス}

\subsection{1 可食農産物}

Fig.9 にブロッコリーの熱分解特性を示す。

ガス化開始温度 Tb 点は 495K であり、DTA 曲線の Tc 点は、 


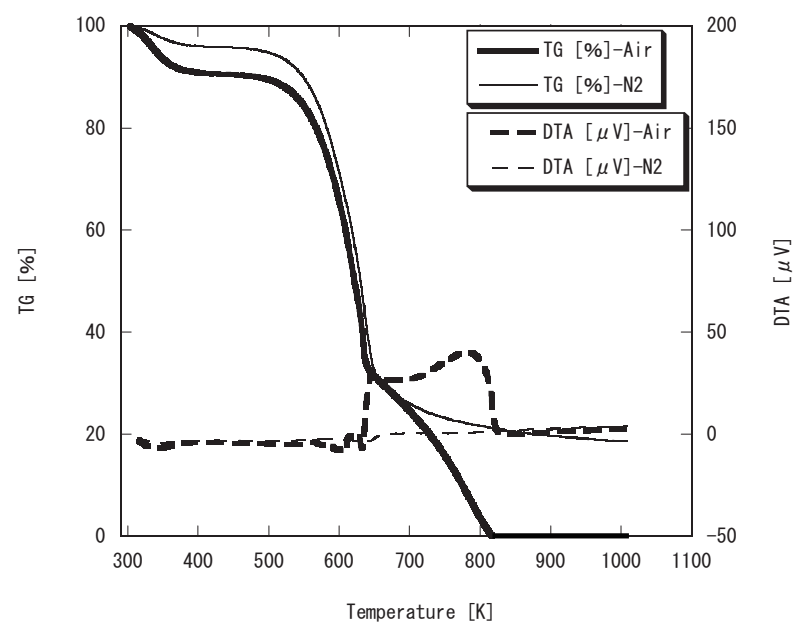

Fig.14 Thermal Decomposition Curve for Pruning Peach

730K であることが読み取れる。さらに、ガス化領域におけ る最大傾斜度 $\mathrm{M}$ は、 $0.5 \times 10^{-2}(1 / \mathrm{K})$ であった。

$\mathrm{TG}$ 曲線の形状および最大傾斜度から、試料として用い たバイオマスの中でも比較的緩やかにガス化が進行してい ることを示している。さらに、DTA 曲線の形状についても、 $750 \mathrm{~K}$ 付近の温度を中心に緩慢な発熱特性を有していること を示唆している。

\subsection{2 食品加工残椬}

Fig.10、Fig.11に芋焼酎滓とオカラの熱分解特性を示す。

芋焼酎滓とオカラのガス化開始温度 $\mathrm{Tb}$ 点はそれぞれ 500K、510Kであり、DTA 曲線の Tc 点は、芋焼酎滓が

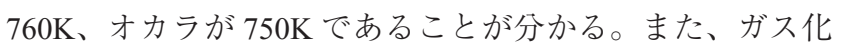
領域における最大の傾き度 $\mathrm{M}$ は、芋焼酎涬が $0.45 \times 10^{-2}$ （1/

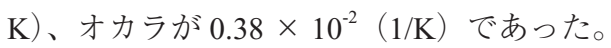

芋焼酎滓、オカラともにガス化領域における傾きが小さ く、DTA 曲線からも他のバイオマスと比べて発熱特性が高 温側に寄っていることから、比較的緻密質な固定炭素形態 であることを示唆している。

\subsection{3 厨芥加工残椬}

Fig.12、Fig.13 にコーヒー漳とお茶滓の熱分解特性を示 す。

コーヒー涬のガス化開始温度 $\mathrm{Tb}$ 点は $550 \mathrm{~K}$ であり、お茶

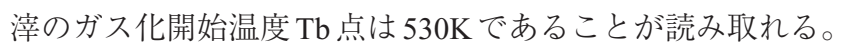
また、DTA 曲線の Tc 点は、コーヒー滓が 790K、お茶滓は $740 \mathrm{~K}$ であることが分かる。さらに、ガス化領域における最 大傾斜度 $\mathrm{M}$ は、コーヒー滓が $0.48 \times 10^{-2}(1 / \mathrm{K}) 、 お$ 茶滓が 0.54 $\times 10^{-2}(1 / \mathrm{K})$ であった。

コーヒー漳とお茶滓の DTA 曲線に着目すると、お茶漳 は幅広い温度範囲で発熱特性を示しているのに対し、コー ヒー滓は温度範囲が狭く $200 \mathrm{~K}$ 程度であり、高温側では シャープなスパイク状の発熱特性を示している。

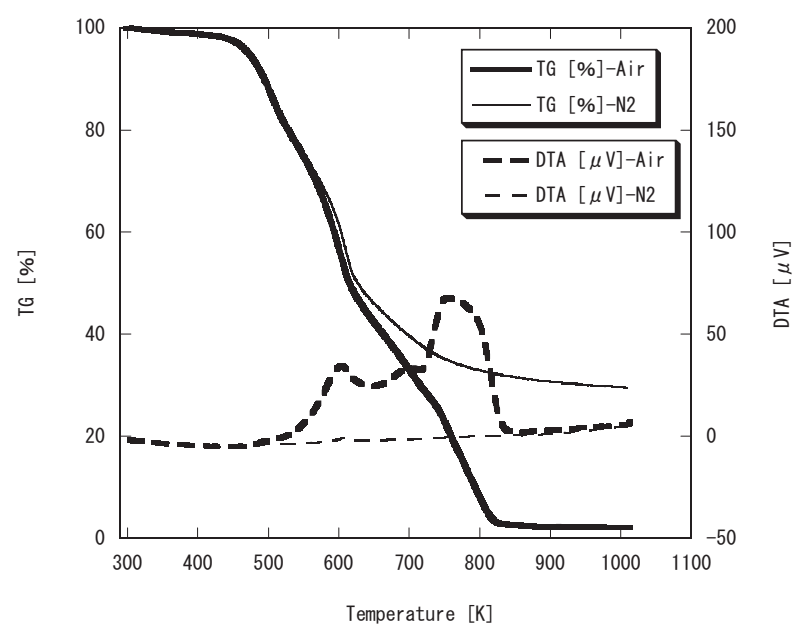

Fig.15 Thermal Decomposition Curve for Apple Grounds

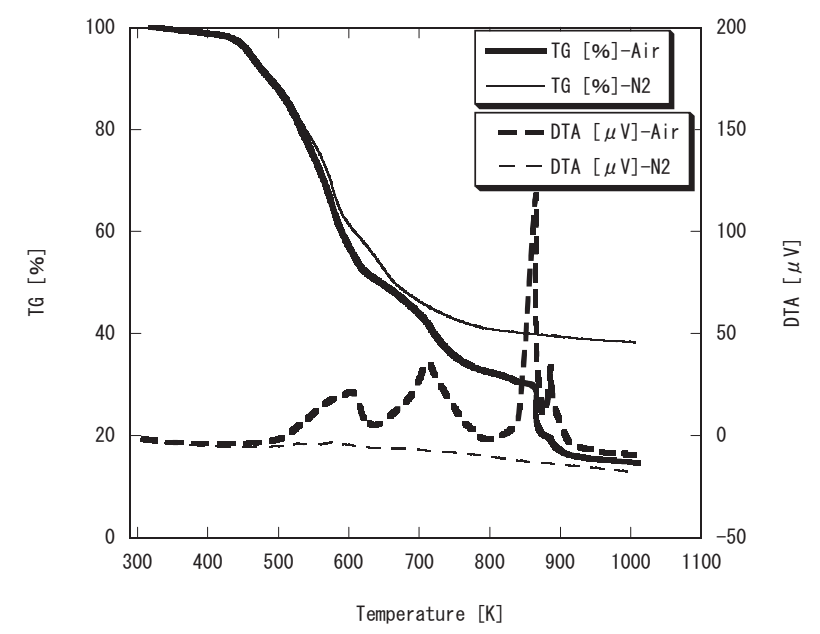

Fig.16 Thermal Decomposition Curve for Banana Peel

\section{4 果樹系バイオマス}

\section{4 .1 樹部}

Fig.14 に桃の剪定枝の熱分解特性を示す。

ガス化開始温度 $\mathrm{Tb}$ 点は $570 \mathrm{~K}$ であることが分かる。また、 DTA 曲線の Tc 点は 780K であった。さらに、ガス化領域に おける最大傾斜度 $\mathrm{M}$ は、 $0.65 \times 10^{-2}(1 / \mathrm{K})$ であった。

この TG 曲線のガス化領域における形状は、木質系バイ オマスであるスギ幹部の特性に酷似している。また DTA 曲 線より発熱特性の形状を見ると、繊維質な莘の発熱特性に 似ている。このことから、骨格成分の含有比率はセルロー ス成分が多くなっているものと理解できる。

\section{4 .2 果部}

Fig.15、Fig.16にリンゴ漳とバナナの皮の熱分解特性を 示す。

ガス化開始温度 $\mathrm{Tb}$ 点は、リンゴ滓が $520 \mathrm{~K}$ 、バナナの皮 が495K と得られた。また、DTA 曲線の Tc 点は、リンゴ 
多様なバイオマス資源の組成·熱分解分析から抽出した特性とその相関（水野·森田・井田・難波・㴊端・澤井）

Table 2 Legend of Raw Biomass on Each Correlation Chart

\begin{tabular}{|l|l|}
\hline Trunk of Cedar & Bark of Cedar \\
\hline Konara Oak & $\Delta$ Sakura \\
\hline Reed & Bamboo \\
\hline Broccoli & $\square$ Distilled Spirit Grounds \\
\hline Bean Curd Refuse & $\Delta$ Coffee Grounds \\
\hline X Tea Grounds & $\diamond$ Pruning Peach \\
\hline$\square$ Apple Grounds & $\bigcirc$ Banana Peel \\
\hline
\end{tabular}

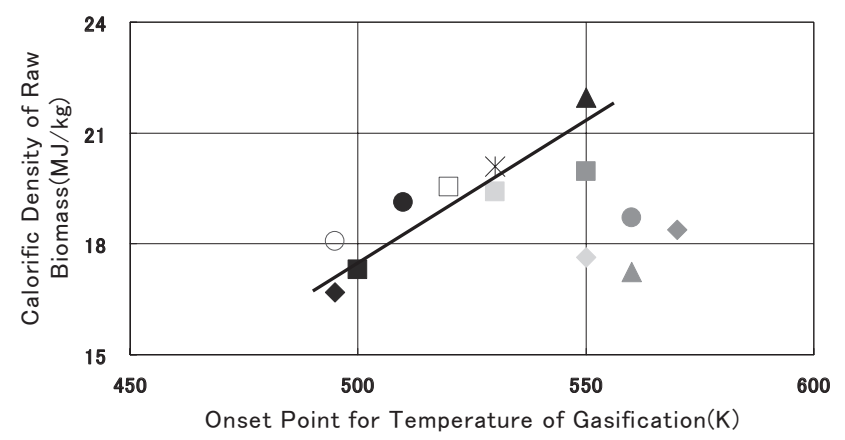

Fig.17 Correlation between Total Calorific for Unit Weight and Onset Points for Temperature of Gasification

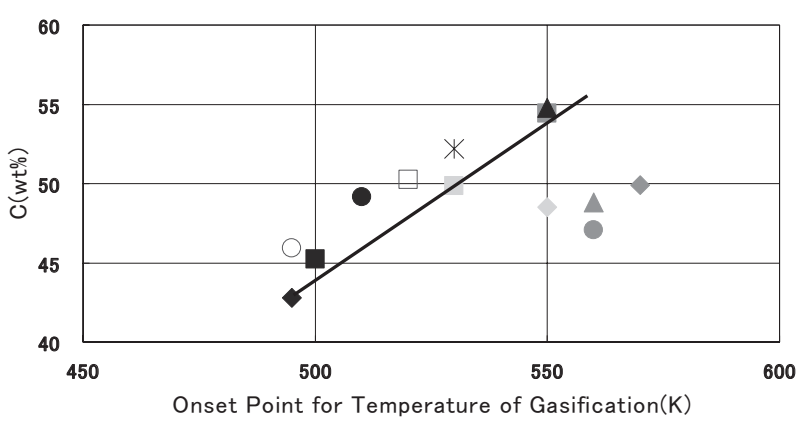

Fig.18 Correlation between Atomic Carbon Ratio and Onset Points for Temperature of Gasification

滓が $760 \mathrm{~K}$ 、バナナの皮が $870 \mathrm{~K}$ という結果を得た。さらに、 ガス化領域における最大傾斜度 M は、リンゴ滓が $0.49 \times$ $10^{-2}(1 / \mathrm{K})$ 、バナナの皮が $0.40 \times 10^{-2}(1 / \mathrm{K})$ であった。

バナナの皮の DTA 曲線の $850 \mathrm{~K}$ 付近でのスパイク状の発 熱特性を見ると、他のバイオマスにない高温特性を有して いることが伺える。

\section{4. エネルギー及び形態構造相関}

以上の定量的な熱分解分析に基づき、エネルギー的な観 点からバイオマスの総発熱量 $(\mathrm{kJ} / \mathrm{kg})$ と含有炭素の形態構 造の観点から炭素原子比率 (wt\%) との相関を論じる。

Table 2 に各相関図に用いた各種バイオマスの凡例を、

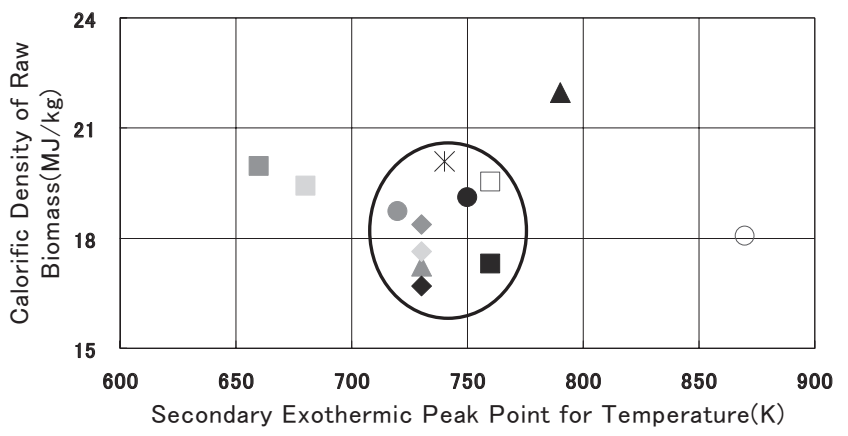

Fig.19 Correlation between Total Calorific for Unit Weight and Secondary Exothermic Peak Points for Temperature in DTA Curve

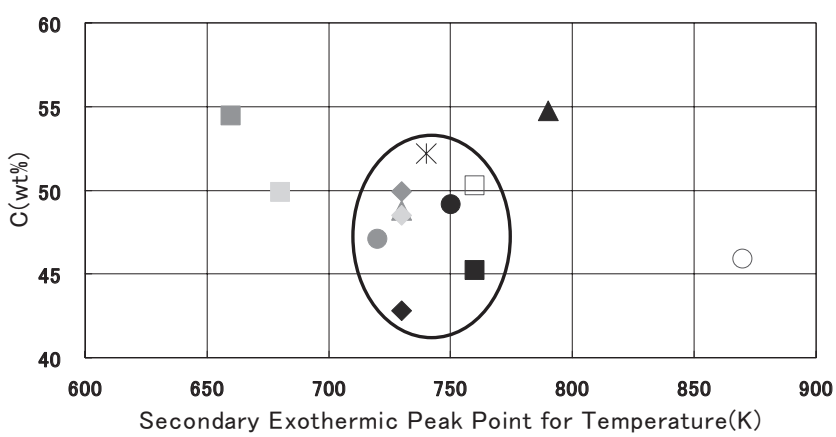

Fig.20 Correlation between Atomic Carbon Ratio and Secondary Exothermic Peak Points for Temperature in DTA Curve

Fig.17、Fig.18 には各種バイオマスのガス化開始温度 $\mathrm{Tb}$ 点 と総発熱量および炭素原子比率との関係を示す。

両図ともに、ガス化開始温度 $\mathrm{Tb}$ 点に対して、ほぼ正比 例の関係にある。Fig.17では、ガス化過程の初期のガス化 開始温度 $\mathrm{Tb}$ 点が低いほど総発熱量が少なく、高いほど総 発熱量が多い関係にあることが得られた。エネルギー的な 観点からは、その傾きが $80 \mathrm{~kJ} / \mathrm{K}$ の差が定量的に決定できる ことから、例えばガス化に要する外部エネルギー供給量の 差を算術できることになる。

しかし、木質系バイオマスおよび草本系バイオマスにお いて、ガス化開始温度 $\mathrm{Tb}$ 点が高いのに対して、総発熱量 が他のバイオマスに比べ $10 \%$ 程度低い。このことは、セル ロースが極めて発達している、すなわちセルロースの含有 比率の多いバイオマス特有の傾向である可能性があり、含 有炭素の形態構造の差異を定量的に分析する必要がある。

Fig.18もほぼ正比例の関係にあることから、ガス化特性 における性状については上述と同じ推察ができる。特に、 原子比率との相関が顕著に現れていることから、バイオマ スの形態構造との関連の議論が必要になることを示唆して いる。

Fig.19、Fig.20に各種バイオマスの DTA 曲線の 2 つめの 発熱ピーク温度 Tc 点と総発熱量および炭素原子比率との 


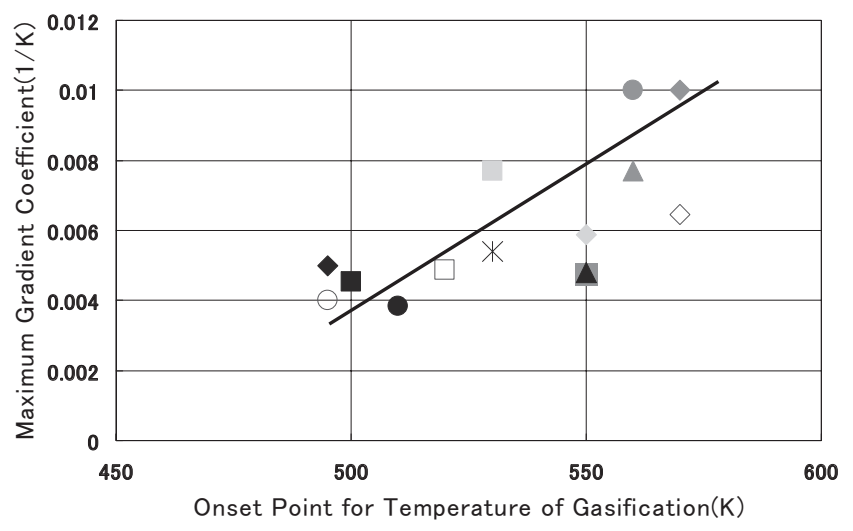

Fig.21 Correlation between Maximum Gradient Coefficient for Effect on Gasification Process and Onset Points for Temperature of Gasification

関係を示す。

両図より、各種バイオマスの 2 つめ発熱ピークが、そ の種類や総発熱量、炭素原子比率に寄らず、 $750 \mathrm{~K}$ 付近に集 中していることが分かる。これは、バイオマスに含まれる ガス化過程後の残炭成分における発熱特性が均一な性質に 転換されることを表していると理解される。しかし、バナ ナの皮が果樹系バイオマスの主にペクチン成分による影響 を受けているとされる特異な性状を発現することは興味深 w。

次に、Fig.21にガス化のプロセスを定量的に指標可能な ガス化開始温度 $\mathrm{Tb}$ 点と温度幅に対するガス化率に帰属す る傾斜度 $\mathrm{M}$ との関係を示す。ガス化過程の最大傾斜度 $\mathrm{M}$ とガス化の開始初期温度は、正比例の関係にあることが示 された。このことは、ガス化の開始温度が高いほど、温度 幅に対するガス化率が多くなる傾向にあることを示してい る。Fig.17、Fig.18の結果と合わせて考察すると、バイオ マスの形態構造上、炭素原子比率が高いバイオマスほどガ ス化開始温度が高温にシフトするが、温度幅に対するガス 化の割合は多くなることを示唆し、また相対的に発熱量も 多くなっている。

\section{5. 結言}

本研究では、バイオマスを組成・熱分解分析からその特 性を定量的に解析するために、多種多様に存在するバイオ マスを属性ごとにわけ、組成・熱分解特性の変化とその相 関を元に、重量周囲曲線からガス化開始温度と吸発熱特性
曲線から 2 つの発熱ピーク温度、重量周囲曲線からガス 化領域における最大傾斜度に関して 2 つ抽出点と 1 つの 抽出項目を設定し、それらの相関から次のような結果を得 た。

(1) 光合成に起因するバイオマスに含まれる 3 つの主成分 であるセルロース、ヘミセルロース、リグニンの含有 比率がバイオマスごとに異なるために、バイオマスの 属性ごとに出現する熱分解特性の傾向に違いがあるこ とを示した。

(2) ガス化開始温度と総発熱量および炭素原子比率の相関 からガス化開始温度の差異により、エネルギー的な観 点からは $80 \mathrm{~kJ} / \mathrm{K}$ 、形態構造的な観点からは $0.2 \mathrm{wt} \% / \mathrm{K} の$ 差が生じることが分かった。

(3) 各種バイオマスに含まれる残炭成分はほぼ均一に $750 \mathrm{~K}$ 付近で発熱することを示した。

(4) バイオマスの属性により、ガス化開始温度の差異によ る総発熱量および温度幅に対するガス化率の増加率は 異なるが、バイオマス全体を巨視的に見ると、ガス化 開始温度が $50 \mathrm{~K}$ 高温側に移ることにより、総発熱量が $25 \%$ 増加するとともに、ガス化率も約 $100 \%$ 増加するこ とを示した。

\section{謝 辞}

本研究の分析の一部は、平成 18 年度（財）鉄鋼業環境保 全技術開発基金、平成 19 年度（社）日本鉄鋼協会・鉄鋼研 究振興助成の支援により行なわれた。ここに謝意を表す。

\section{引用文献}

1) 農林水産省：バイオマス・ニッポン、http://www.maff.go.jp/j/ biomass/index.html、2002

2) 日本エネルギー学会：バイオマスハンドブック、(2002) 113-119

3) 木谷収：バイオマス、コロナ社、(2004) 12-13

4) 原口隆英、寺島典二、臼田誠人、越島哲夫、坂井克己、諸星 紀幸、寺谷文之、甲斐勇二、志水一允、榊原彰 : 木材の化学、 文永堂出版、(1985) 2-5、112

5) 高橋徹、中山義雄: 木材科学講座 3 物理、海青社、(1993) 48-50

6) 井田民男、難波邦彦、佐野寛：バイオマス揮発成分を利活用 するための熱分析と基礎燃燒特性、高温学会誌·Vol.33、(2007)、 No.1 43-47

7) 城代進、鮫島一彦 : 木材科学講座 4 化学、海青社、(1993) 4162 